\title{
How do users interact with photovoltaic-powered products? Investigating 100 'lead-users' and 6 PV products
}

\author{
Georgia Apostolou* \\ Design for Sustainability, \\ Faculty of Industrial Design Engineering, \\ Delft University of Technology, \\ Landbergstraat 15, 2628CE Delft, The Netherlands \\ Email: g.apostolou@tudelft.nl \\ *Corresponding author
}

\section{Angèle Reinders}

Design for Sustainability,

Faculty of Industrial Design Engineering,

Delft University of Technology,

Landbergstraat 15, 2628CE Delft, The Netherlands

and

Department of Design, Production and Management,

Faculty of Engineering Technology,

University of Twente,

P.O. Box 217, 7500AE Enschede, The Netherlands

Email: a.h.m.e.reinders@utwente.nl

\begin{abstract}
In order to better understand how 'lead-users' interact with PV-powered products, the behaviour of 100 people interacting with six different PV-powered products in their daily life was analysed. The sample of respondents to be observed consisted of 20 groups, each one formed by five students of Industrial Design Engineering at Technical University of Delft (TU Delft). The tested PV products are: the IKEA Sunnan lamp, the Waka Waka light, the Waka Waka power (charger and light), the Little Sun light, the Logitech solar keyboard and the Beurer kitchen weight scale. In this study the design of the six tested PV products was analysed, lead-users' expectations were outlined, as well as their opinion of the products' performance during and after use was addressed. Results show that respondents need reliable PV products with appealing design and improved performance.
\end{abstract}

Keywords: photovoltaic; PV; PV-powered; PV products; user behaviour; lead-user; interaction; users' expectations; design; performance; aesthetics.

Reference to this paper should be made as follows: Apostolou, G. and Reinders, A. (2016) 'How do users interact with photovoltaic-powered products? Investigating 100 'lead-users' and 6 PV products', J. Design Research, Vol. 14, No. 1, pp.66-93. 


\begin{abstract}
Biographical notes: Georgia Apostolou holds an MSc in Mechanical Engineering from the National Technical University of Athens (NTUA) in Greece. She specialised in alternative sources of energy and mainly in solar energy and photovoltaics. She finished her studies in 2010. Currently, she is working on her $\mathrm{PhD}$ in Industrial Design Engineering Department at Delft University of Technology in the Netherlands, with supervision of Angele Reinders. Her research focuses on photovoltaic products for indoor use, indoor irradiance conditions and users' interaction with PV products.
\end{abstract}

Angèle Reinders is Associate Professor at the Department of Design, Production and Management of the University of Twente, the Netherlands, and Emeritus Professor at the Faculty of Industrial Design Engineering of TU Delft. She has a vast experience with sustainable product development in cooperation with companies i.e. products incorporating photovoltaic solar energy technology, PV modules, lighting products and solar powered boats. Also she has practical experience with monitoring, evaluation and simulation of sustainable energy systems. She supervises several PhD students on the evaluation and design of products and services with integrated sustainable energy solutions. Also, she is an editor at Wiley \& Sons and IEEE Journal of Photovoltaics.

This paper is a revised and expanded version of a paper entitled 'Users' interaction with PV-powered products: an evaluation of 6 products by 100 end-users' presented at the Proceeding of 42nd IEEE Photovoltaic Specialists Conference, Poster Presentation, New Orleans, LA, 14-19 June 2015.

\title{
1 Introduction
}

Technological advancements in photovoltaic (PV) cells' technology have made possible solar to electric conversion in a variety of consumer products (Apostolou and Reinders, 2014, 2012; Reinders and van Sark, 2012; Reinders et al., 2012). PV cells are considered an effective solution for energy production, when applied to consumer products, owing to the decreasing prices of the PV cells, as well as their continuously growing efficiency (Apostolou et al., 2014). However, in today's competitive world it is always a question whether solar-powered devices are capable of being more attractive to the buyer than their plug-into-the-wall or battery-powered counterparts or not. Although purely out of the principle of energy conservation and the idea of sustainability, PV powered products are preferable, it is still important to design a product that effectively meets both the users' needs and their expectations.

Because of the newness of PV powered products, in this study, we will look at the 'lead-users' and not the regular users. Eric von Hippel first introduced the term 'lead-user' in 1986 (von Hippel, 1986). Lead users have a need for products that are not identified yet by regular users and will become general in the market in the future. Lead users can forecast future needs, propose solutions and redesign ideas in order to contribute towards the innovation of products and services (von Hippel, 1986, 1982). The aim of this study is to observe lead-users when interacting with PV products, to identify their expectations, needs and feelings and to finally see if PV products correspond efficiently to their wishes, abilities and prospects. 
When investigating a number of PV integrated products of different categories, one can observe that there are no specific guidelines that designers can use in order to estimate the available energy from an indoor or outdoor environment and the fraction of this energy that can be extracted by the PV system of the product (Apostolou et al., 2014). As a result these products have often insufficient energy systems, which lead to poor performance, or they are too expensive because of their possible oversized energy system or the extra material they might use (Apostolou and Reinders, 2014, 2012; Apostolou et al., 2014).

Furthermore, the majority of these products are unattractive to the consumers, owing to the low quality and low-cost materials that are used (e.g. for casings) or the inelegant design of the products. As these products are targeted at the consumers, design guidelines should be drawn to address not only the technical aspects of these products, but also the users' interaction with them, as well as the appeal of the products' design.

Although markets are crowded with PV products, consumers seem rather sceptical about their performance, usability and aesthetics. Therefore it is important not only for PV products to meet adequately users' needs but also for designers and manufactures to focus on the technology and on users' interaction with the products, as well.

Figure 1 PV products in our study, (a) Waka Waka light (b) Waka Waka power light and charger (c) Sunnan IKEA lamp (d) Little Sun light (e) Beurer kitchen weight scale (f) Logitech solar keyboard (see online version for colours)

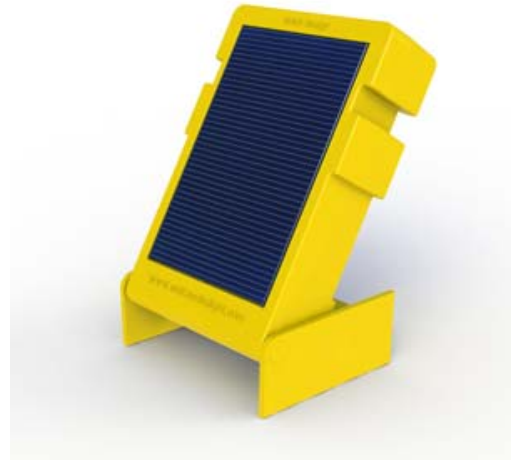

(a)

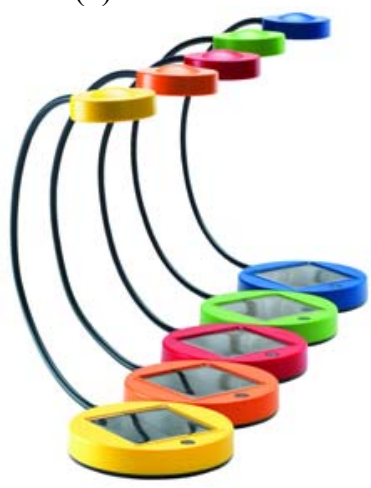

(c)

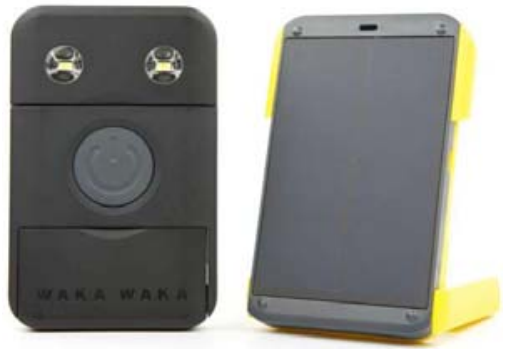

(b)

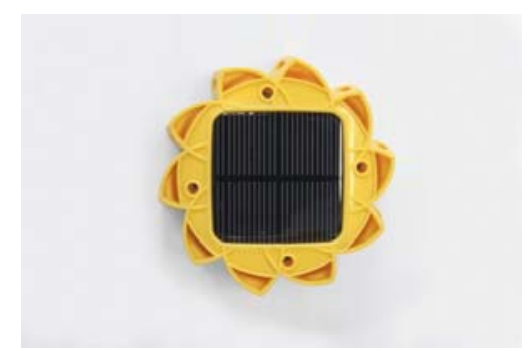

(d) 
Figure 1 PV products in our study, (a) Waka Waka light (b) Waka Waka power light and charger (c) Sunnan IKEA lamp (d) Little Sun light (e) Beurer kitchen weight scale (f) Logitech solar keyboard (continued) (see online version for colours)

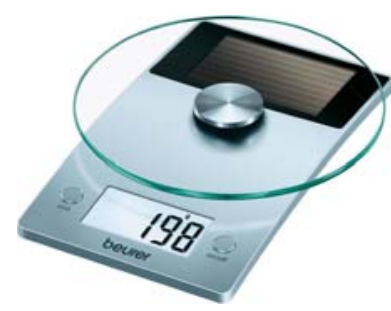

(e)

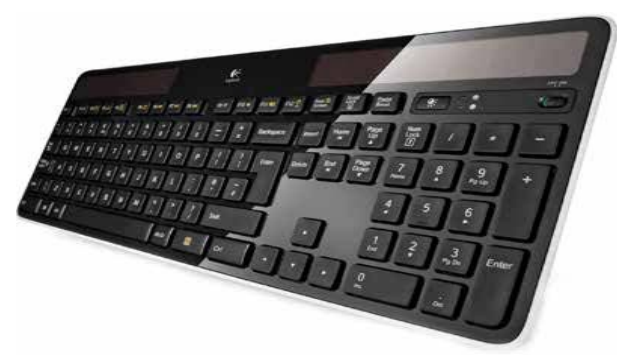

(f)

Various methods could be used to identify respondents' needs, such as market research, real-life surveillance or even lab-observation for specific periods of time, focus groups and quantitative analyses (Bakker et al., 2010; Fulton, 2003; Jelsma, 2006; Kakee, 2008). Nevertheless, these methods often fail to foresee precisely whether respondents will understand the tested products' technologies. In this study both quantitative and qualitative methods will be used. The hypothesis of this survey is that the tested PV products do not fully satisfy lead-users' wishes, abilities and expectations.

The feature that distinguishes this study in the field, is the fact that more than one PV product was tested in real conditions and statistics from lead-users' interaction with the products is higher than in other studies executed so far (Bakker et al., 2010; Kakee, 2008, Smit et al., 2002; Vredenburg et al., 2002; Reich et al., 2008, 2007; Wever et al., 2008). The outcome of this study might be useful for designers, as they could have an overview of lead-users' thoughts about PV products and in this way they could evaluate their proposals and ideas about the products and finally offer better services or design more reliable products, which will fit respondents' desires. This study does not aim to investigate in depth user behaviour from a social and psychological point of view. It intends to be used in parallel with technical and design features of PV products and offer a perspective of lead-users' thoughts to designers.

The tested PV products entail four lighting products (the Sunnan lamp by IKEA, the Waka Waka light, the Waka Waka power and the Little Sun light), and two PV products for indoor use (a solar kitchen weight scale by Beurer and the solar keyboard by Logitech). The data of this study, as well as the observation of the lead-users during their interaction with the products, are mainly based on the selection of 21 reports regarding the tested PV products, written from 2011 to 2014. Table 1 gives an overview of the tested PV products, their main functions, as well as the average number of lead-users that interacted with each product. The collected data and the measurements regarding the technical analysis of the products were conducted under the supervision of the author.

In the following we will present a literature research on user studies (in Section 2), the methodology applied (in Section 3), the results (Section 4) and in the end we will finish the paper with the conclusions and discussion of our findings (Section 5). 
Table 1 Reports: user interaction with PV products (2011-2014)

\begin{tabular}{lcccc}
\hline PV products & Function & $\begin{array}{c}\text { Designed } \\
\text { to be used }\end{array}$ & $\begin{array}{c}\text { Number of } \\
\text { reports }\end{array}$ & $\begin{array}{c}\text { Number of } \\
\text { users }\end{array}$ \\
\hline Sunnan lamp & Lighting & $\begin{array}{c}\text { Indoors/ } \\
\text { outdoors } \\
\text { Waka Waka light }\end{array}$ & 10 & 50 \\
Waka Waka power & $\begin{array}{c}\text { Lighting } \\
\text { Charging/ } \\
\text { lighting }\end{array}$ & $\begin{array}{c}\text { Outdoors } \\
\text { Outdoors }\end{array}$ & 3 & 1 \\
Little Sun light & $\begin{array}{c}\text { Lighting } \\
\text { Kitchen }\end{array}$ & Outdoors & 3 & 4 \\
Beurer kitchen scale & Indoors & 2 & 15 \\
Logitech solar keyboard & $\begin{array}{c}\text { Office } \\
\text { equipment }\end{array}$ & Indoors & 2 & 10 \\
Total: 6 products & & 21 & 6 \\
\hline
\end{tabular}

\section{Literature research on user studies}

The issues of consumer behaviour and sustainable product design have been criticised extensively by many researchers (Reinders et al., 2012; Bakker et al., 2010; Smit et al., 2002; Vredenburg et al., 2002; Wever et al., 2008; Shackel, 1984; Rodríguez and Boks, 2005). However, there are still questions that need to be answered.

Jelsma and Knot (2002) pointed out that user's behaviour can be led and be determined by the design of a product (Wever et al., 2008; Jelsma and Knot, 2002). This approach seems applicable to the design of PV products, since the PV products need the specific attention of the user and they could control user behaviour. However, it seems that users cannot easily adapt a specific behaviour and therefore a design based on this approach could not be effective. Users prefer to be autonomous and independent on the product and they are not willing to change their daily behaviour and habits.

Rodríguez and Boks (2005) chose a rather different approach, trying to adapt the design of the product to the user's needs (Wever et al., 2008; Rodríguez and Boks, 2005). Regarding the design of a PV product, it seems that Rodriguez and Boks' approach is more appropriate than Jelsma and Knot's. It could be more fruitful to design a PV product, according to the user's needs and expectations. However, in order to succeed this, it is important to discover and analyse what users expect from these products. Furthermore, Vredenburg et al. (2002) pointed out the quality of products by focusing on users' abilities and wishes, aiming to enhance the user interaction with the product.

Rooden and Kanis (2000) suggested an advanced model for user-product interaction, which is based on Shackel's (1984) model, and it contains user's features, product's features, and details about the relation between the user, the product and the place of interaction (Wever et al., 2008; Shackel, 1984; Rooden and Kanis, 2000). The model also offers feedback information to the user on the performance of the product, as well as the possible side effects. This model is demonstrated in Figure 2. 
Figure 2 The model of Rooden and Kanis (2000) illustrating the user-product interaction (scheme designed by the author)

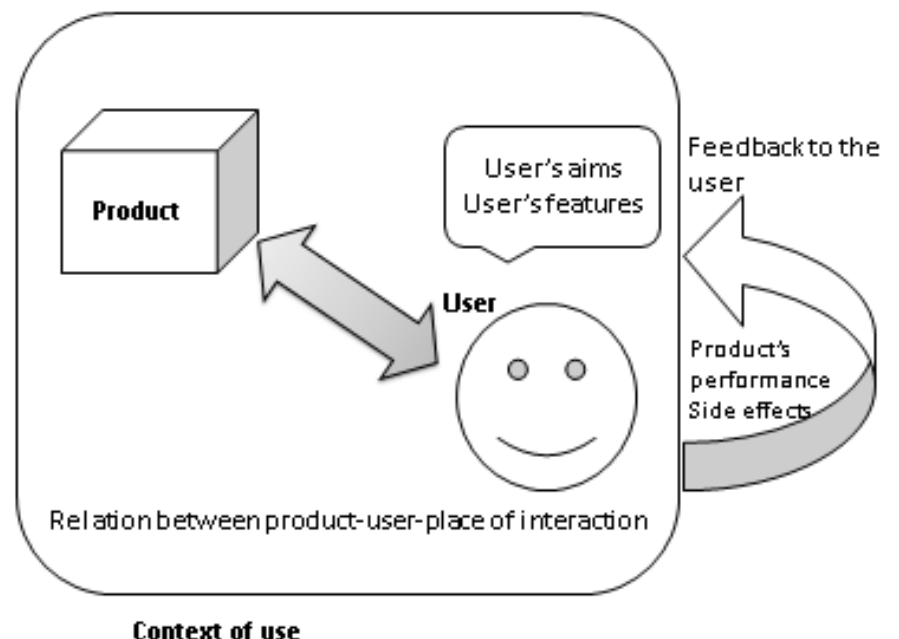

Source: Wever et al. (2008) and Rooden and Kanis (2000)

The model of Rooden and Kanis will be used in our study for the investigation of the lead-users' interaction with PV products. Through observation during the field trial, a questionnaire and written reports of respondents, we will analyse the lead-user itself, the product, the place of interaction and their relation, aiming at a user-centred design of products.

Sanders (2002) talks about the different experience characteristics of users and divide them in four categories: the 'obvious' which depicts things that people say or think, the 'visible' which refers to what people do, the 'unspoken' or 'tacit' which are things that people feel or be aware of, and the 'dormant' which are people's dreams (Sanders, 2006a, 2006b, 2002). In our study through lead-users' interaction with the PV products, their daily notes on the workbook and their thoughts, we will try to uncover all the above aspects and focus mainly on the unspoken and dormant features, which are important for designers.

\section{Methodology}

The study of the lead-users' interaction with PV products took place during the academic years 2013-2014 and 2014-2015 for a PV Workshop, at Technical University of Delft (TU Delft). The sample of the respondents consisted of 100 lead-users (75 men and 25 women) at the age of 20 to 35 years old. Around $90 \%$ of the respondents are Dutch and the rest originate from EU or India. All the participants were bachelor students of the Industrial Design Engineering department. Before the field trial, which lasted one to two weeks, the lead-users could choose and decide which PV product they would like to use, among a selection of 12 PV products.

Respondents of this study may be characterised by the term 'lead-users', as it was defined in the introduction of this study. Lead-users were asked to follow some specific tasks with the products: first to use the photovoltaic-powered product in their daily 
routine and then to disassemble and analyse it, in order to identify its main components and to evaluate its feasibility from a technical, practical, economic and environmental point of view. From a technical point of view, the energy conversion efficiency of the solar cells was defined, the theoretical charging time of the battery, the current-voltage and power-voltage curves and the maximum power point, by conducting measurements at different levels of irradiation. Moreover, the application of solar cells in the products was evaluated and concepts or redesign ideas for a potential improvement of the PV product's system were proposed. The respondents used the PV product as a part of their daily routine. The issues that they had to note during the trial week were the following:

- their initial expectations from the product before using it

- evaluation of the product after use it for a short period of time

- user pattern and use frequency

- the ease of use and general functioning of the product

- emerging frustrations or feelings of satisfaction/dissatisfaction with the PV product

- $\quad$ suggestions for improvement

- ways to use the product in their daily life.

The methods that were used to gather the research elements regarding the respondents' comments before, during and after the field trial, as well as their frustrations, problems and suggestions, were notebooks for writing down their daily routine and their feedback during their interaction with the product. These notebooks were presented in formal reports written by the students and were used by the authors of this research. The authors organised the data collected from the reports, categorised them and draw conclusions. Furthermore, lead-users' interaction was based on self-observation during their daily routine with the product, while direct observation method was applied during the analysis of the technical features of the PV products, as well as during the performance's tests.

Besides the above issues, a questionnaire of 17 questions was set up in order to collect information about lead-users and their interaction with the PV products. Two sets of questions were formed; the first one consisted of closed-questions, where the possible answers were among a scale of satisfaction (from 0 - low to 5 - high), while the second set consisted of open questions, where the respondents were asked to elaborate their opinions and thoughts.

The questionnaire was first distributed to the lead-users, since its aim was to outline their first reactions and thoughts about the PV products after the respondents' early interaction with the product. Lead-users first answered the closed-questions of the questionnaire and after a few days of living with the product they continued with the open questions. After the questionnaire was completed and during the field trial the lead-users were self- or directly-observed interacting with the product and by the end of this period they already had prepared the report with their actual experience. Lead-users' answers from the questionnaire will be presented in the form of statistics. Further results of this study, such as possible re-design of PV products or best-fitted user context with a specific product, as proposed by the respondents in their formal reports, will be analysed and discussed in the results section. 


\section{Results}

\subsection{Analysing lead-users' answers from the questionnaire}

The results depicted the lead-users' expectations at a time before using the product and their evaluation after the field trial. It is interesting to observe the difference between the two stages. During the first contact of the lead-user with the product, and before the field trial starts, lead-users criticise the outlook of the product (e.g. the design, colour, materials, size) and they try to predict its function and usefulness. Around $60 \%$ of the respondents feel comfortable with the product and consider it as 'a nice gadget' to use. First impression is positive. However, there are doubts concerning the functionality and performance of the product.

Table 2 Example of the general evaluation of the PV products, according to the perception of a single user's feedback

\begin{tabular}{|c|c|c|c|}
\hline & Sunnan lamp & Waka Waka light & Waka Waka power \\
\hline Design & $\begin{array}{l}\text { Simple, practical, } \\
\text { unattractive }\end{array}$ & Strong/simple & Strong/simple \\
\hline Usefulness & $\begin{array}{c}\text { Cordless, short battery } \\
\text { lifetime }\end{array}$ & $\begin{array}{l}\text { Cordless, necessary to } \\
\text { developing countries }\end{array}$ & $\begin{array}{l}\text { Cordless, necessary to } \\
\text { developing countries }\end{array}$ \\
\hline Performance & $\begin{array}{l}\text { Insufficient, low } \\
\text { lighting levels }\end{array}$ & Sufficient, strong light & Rather sufficient \\
\hline Price & Affordable & High & High \\
\hline \multirow[t]{2}{*}{ Portability } & + & + & + \\
\hline & Little Sun & Beurer kitchen scale & Logitech solar keyboard \\
\hline Design & $\begin{array}{l}\text { Interesting shape, } \\
\text { attractive }\end{array}$ & Simple, not efficient & Premium, high quality \\
\hline Usefulness & $\begin{array}{l}\text { Cordless, necessary to } \\
\text { developing countries }\end{array}$ & Cordless, nice gadget & $\begin{array}{l}\text { Cordless, power } \\
\text { independent }\end{array}$ \\
\hline Performance & $\begin{array}{l}\text { Depends on the } \\
\text { charging }\end{array}$ & Not precise & $\begin{array}{l}\text { Sufficient enough, } \\
\text { battery status } 100 \% \text { full }\end{array}$ \\
\hline Price & High & High & $\begin{array}{l}\text { High, but worth } \\
\text { the money }\end{array}$ \\
\hline Portability & + & + & + \\
\hline
\end{tabular}

After the field trial, lead-users' feedback, which is in the form of written reports and answered questionnaires, mainly concerns the product's performance; around $40 \%$ of the respondents are totally unsatisfied (see Figure 3), 38\% find the product totally useless (see Figure 4), around $60 \%$ find the design of the product of bad/low quality (see Figure 5), 54\% believe the design of the product is quite simple and can easily be used by everybody (see Figure 6), while only $4 \%$ find it difficult to use the specific product (see Figure 7). $88 \%$ of the respondents would not buy the PV product or propose it to a friend (see Figure 8 ) and around $70 \%$ believe that the price of the PV product does not correspond to its quality and performance (see Figure 9). Table 2 presents some comments regarding the general evaluation of the PV products, based on the lead-users' remarks. Last but not least, around $66 \%$ of the respondents would prefer a product that can be charged by a cable with a plug, instead of a PV-powered product (see Figure 10). 
Figure 3 Lead-users' answers (share \%) to the question: are you satisfied by the PV product's performance? (see online version for colours)

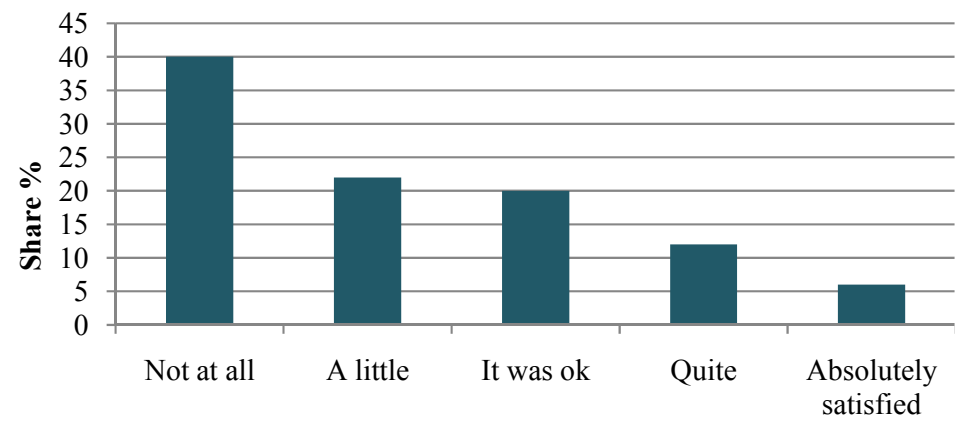

Note: Number of respondents $n=100$.

Figure 4 Lead-users' answers (share \%) to the question: how useful did you find the specific PV product? (see online version for colours)

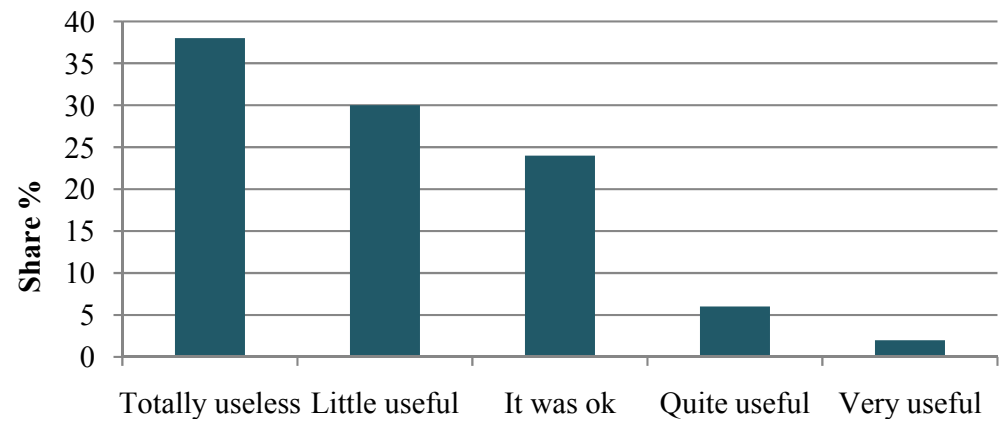

Note: Number of respondents $\mathrm{n}=100$.

Figure 5 Lead-users' answers (share \%) to the question: did you like the design (look) of the PV product you used? (see online version for colours)

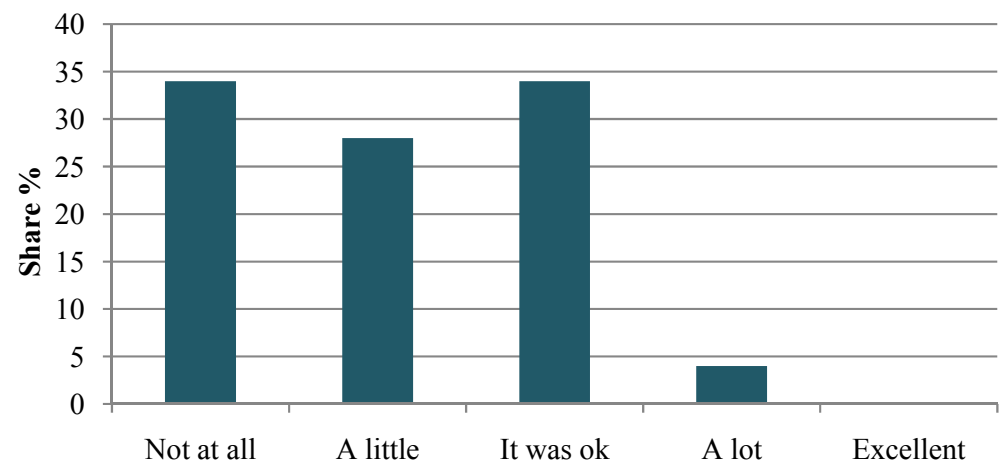

Note: Number of respondents $n=100$. 
Figure 6 Lead-users' answers (share \%) to the question: did you find the product's design complex? (see online version for colours)

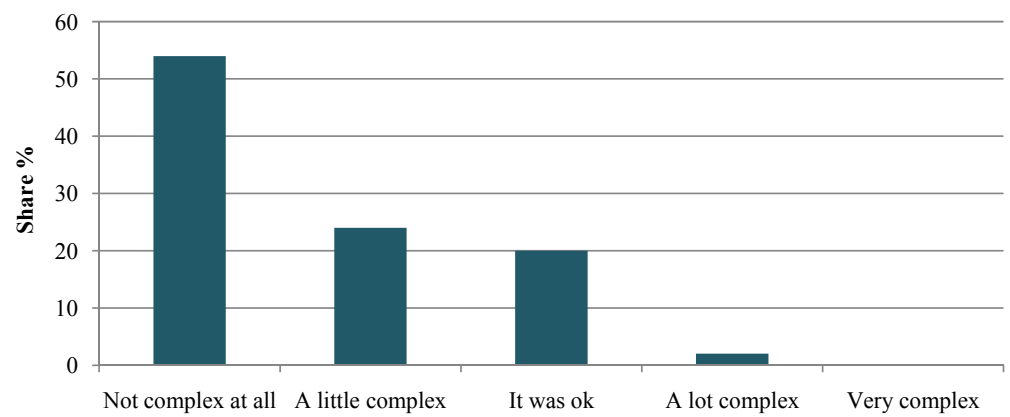

Note: Number of respondents $\mathrm{n}=100$.

Figure 7 Lead-users' answers (share \%) to the question: how easy was it to use the specific PV product? (see online version for colours)

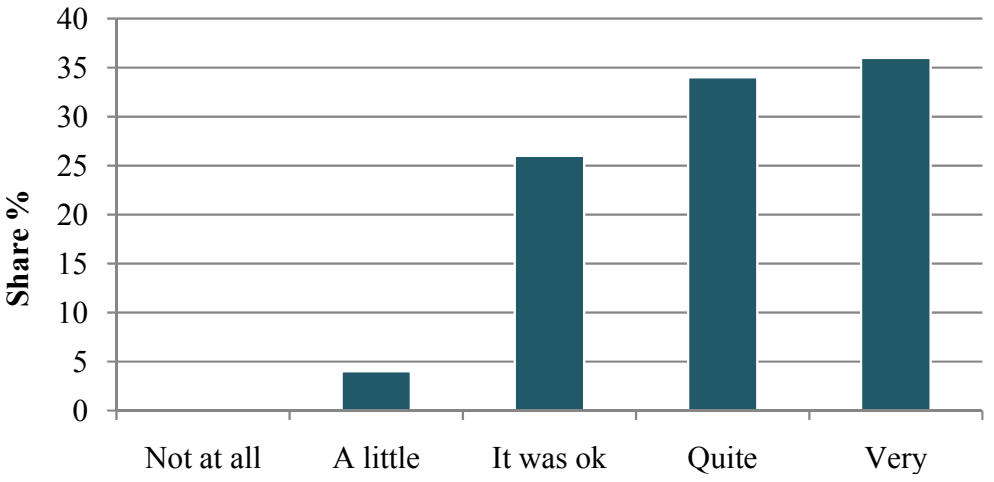

Note: Number of respondents $n=100$.

Figure 8 Lead-users' answers (share \%) to the question: would you buy the PV product you used during the field trial? (see online version for colours)

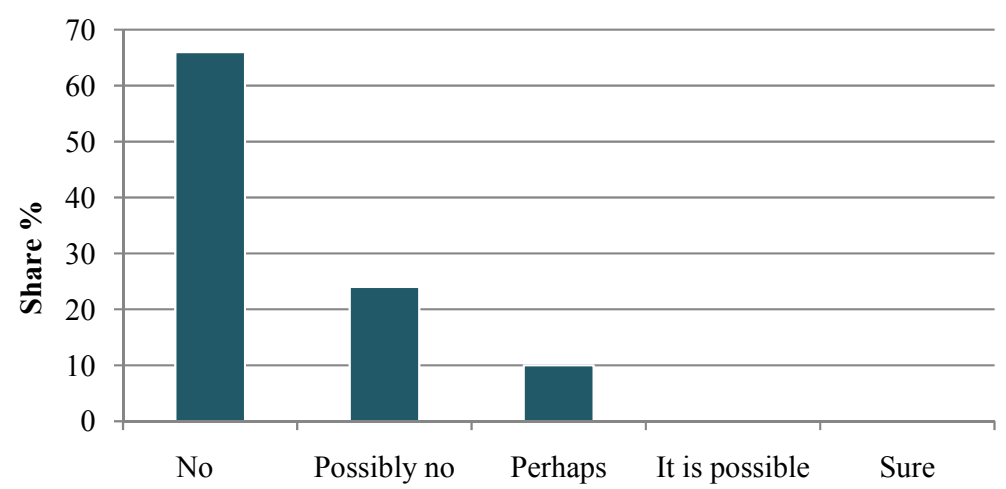

Note: Number of respondents $\mathrm{n}=100$. 
Figure 9 Lead-users' answers (share \%) to the question: do you think the price of the product corresponds to its quality? (see online version for colours)

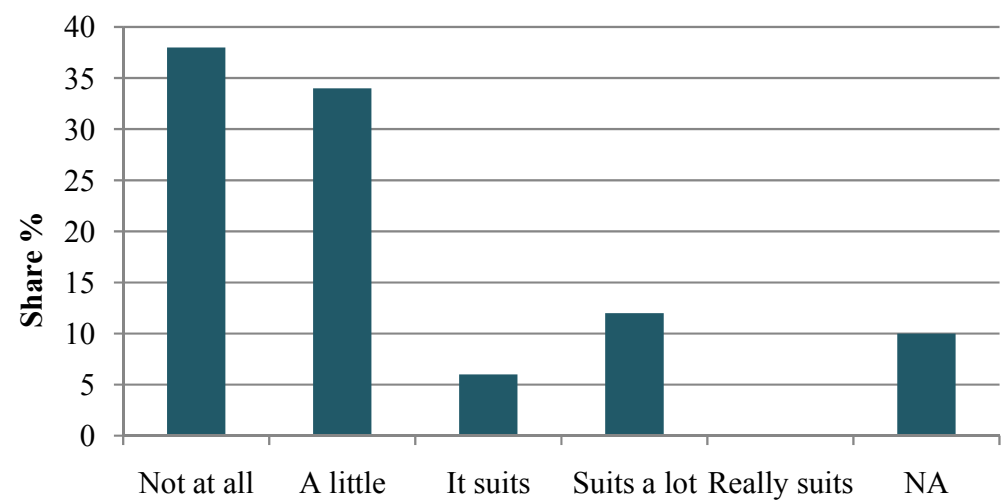

Note: Number of respondents $\mathrm{n}=100$.

Figure 10 Lead-users' answers (share \%) to the question: What would you choose to buy, a PVpowered product or a product with a cable and plug? (see online version for colours)

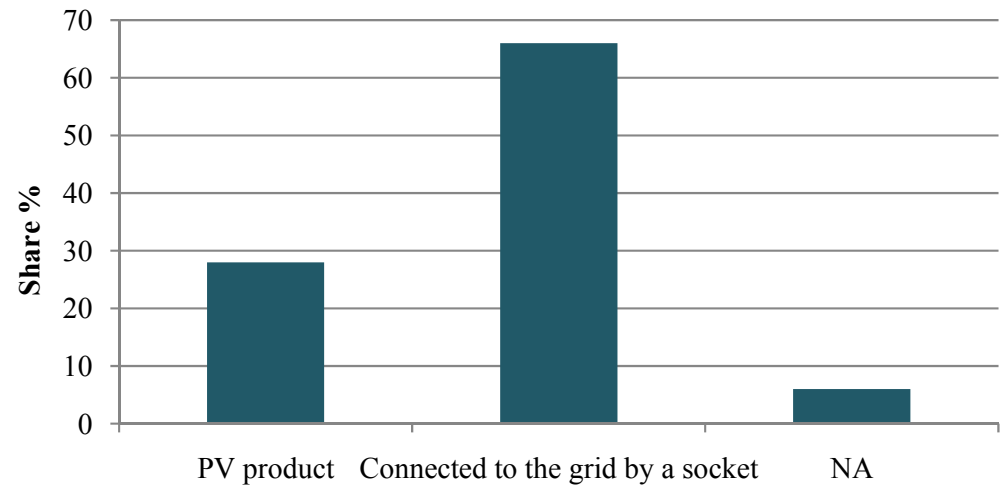

Note: Number of respondents $\mathrm{n}=100$.

Main results show that the lead-users need more reliable PV products, made with materials of good quality that have an interesting and appealing design, and perform sufficiently. Instructions on the packaging/casing of the product and reliable expectations from the manufacturer/designer seem to be important to lead-users, in order to know what to expect from the product and how to use it. Respondents are willing to pay money and buy a PV product if it is useful and works properly. Furthermore, it is noticeable that lead-users are quite positive with PV products that have an environmentally friendly or a social character (e.g. donations to the developing countries when buying a solar-powered lighting product, such as the Waka Waka or the Little Sun light).

\subsection{Lead-users'feedback}

We asked for respondents' personal opinions. Below you will find a selection of statements that indicate lead-users' personal opinions after their interaction with the product, as these are stated in the students' reports. 
"A multi-function PV product is more desirable (e.g. lighting and charging function)"

"I would prefer to buy a product without PV cells. The PV cells must be removed and placed in the sun every day (outside). If I could just leave it inside, then I would reconsider it"

"I would buy the PV product. I do not like wires and batteries are always nowhere when needed"

"I think the specific PV-powered light is a useless product in Holland, due to the lack of sunlight, but in Africa it would be a great product"

"I find it a bit frustrating that the product works well only with heavy sunlight"

"I would definitely buy the PV-powered product. I am happy to spend a little more money for eco-friendly products that use renewable energy"

"I liked the design and the idea of using a PV-powered product. What I did not like was the fact that it did not work late at night, when the sun was down"

"I would buy the grid-connected version of the product, because it is less expensive and it performs better than the PV-powered product"

"The design of the product is ugly, the battery pack did not charge. I am really disappointed by its performance. It is the worst product of the branch"

"What wouldn't I change on the PV product......design, battery capacity, materials, color, use..."

"The overall product needs improvement, but the concept is good. A redevelopment could deliver a better product"

"I would buy the PV product just for fun, if it was cheap more than wanting to use it"

"Grid connection is more reliable than PV"

It can be concluded from the above statements, reflecting only $20 \%$ of the total, that they are very diverse and represent both negative and positive opinions.

\subsection{Analysing lead-users' interaction with the tested PV products}

In this section, the six tested PV products are separately presented and the lead-users' interaction with them is discussed. Respondents' thoughts and ideas for redesign are also addressed, as they were evaluated in the students' reports.

\subsubsection{IKEA Sunnan lamp}

\subsubsection{Product's features}

The Sunnan lamp is a wireless product, which is portable and quite flexible to the user. There is only one button present on the base of the lamp, which makes the lamp's operation quite easy. Furthermore, a movable steel arm is present, as well as three LEDs. The solar cell of the lamp can be detached from the lamp and be charged outdoors or indoors near the windowsill. The Sunnan lamp can be used as: 
- A desk light; for reading, writing.

- A garden table light; using it outdoors on the garden table, when natural light is insufficient.

- A bed light; using it on the bed, while reading a book.

- A flashlight; owing to the product's portability, it can be used as a torch. However, the shape is odd and it is rather difficult to hold the lamp.

\subsubsection{Lead-users' expectations before use}

Initially, the fact that there are no wires permits lead-users to place the lamp where they want, without keeping it near a power socket. Secondly, it seems easy and convenient to use the lamp, since there is only one button to turn it on/off. Thirdly, the movable steel arm enables the lead-user to adjust the angle of the incoming light. Finally, the lamp uses three LEDs, which should be more than enough for a reading light. The solar cell is removable and the user needs to place it under sunlight, instead of doing so with the whole lamp.

\subsubsection{Lead-users' experience and feedback during use}

After the field trial, the lead-users reconsidered some of their initial expectations. Comparing the light to a normal light bulb one issue immediately arises; the light does not diffuse. The light of the LED only covers a circle of about 50 centimetre (when aimed right down from the highest point) and beyond these perimeters the surface is totally dark. The light is concentrated to one spot and does not diffuse in any direction. According to the respondents, this is a drawback of the product.

Figure 11 (a) Current situation vs. (b) ideal situation (see online version for colours)

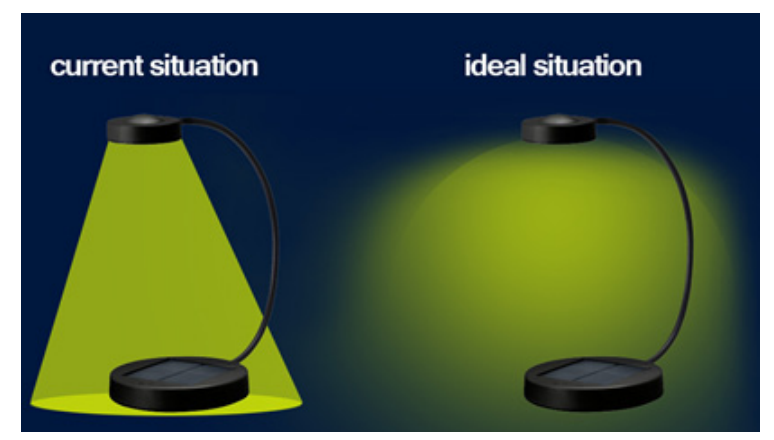

(a)

(b)

Note: In the ideal situation the light diffuses more, which results in a more gradual transition between light and dark.

\subsubsection{General conclusions and discussion after use}

The lamp is solar powered, therefore the lead-user needs to take into account that the battery is charged sufficiently to use it two hours a day, three times a week for desk activities and half an hour a day, five times a week and more, when necessary. Following 
the manual, the lamp needs to be charged for minimal nine hours in sunny conditions and twelve hours in cloudy conditions to function for three hours. On the shortest day of the year there are less than seven light hours, which prevents full charging of the product. For that reason the lamp cannot be used to full potential.

The field trial determined that the actual burning time of the lamp is much longer than is guaranteed, so it is expected that this will compensate the shorter period of exposure to daylight. It is anticipated that with $2 / 3$ of the charging time the duration of light burning will drop with $2 / 3$ also, to around a burning time of five hours. Nevertheless, after the burning time of the three hours mentioned in the manual, the lamp colour gets a different, but warmer tone. This tone is even more comfortable than the clinical light colour. Therefore, it can be stated that the lamp supplies the demanded usage from the target groups, when charged outside.

In reality lead-users will charge the batteries indoors. The irradiation will drop dramatically by a factor of 20 , which means those five hours of burning time anticipated would not be reached by charging it in one day. It is not expected that indoor charging can reach the burning time for the daily use of maximum two and a half hours desired. It will be even more difficult to satisfy the needs for unexpected higher use.

Overall, the resilience of the light was collectively observed. It would not easily run out of charge. A significant difference between high and low power performance state was noticed by the time respondents learnt how to adequately power up the product. The drop off in power was so noticeable that lead-users were forced to reconsider how useful the light was, once the brightness began to dim as the batteries discharged. This is illustrated in the contrasting images below (see Figure 12).

Figure 12 Comparison of the high and the low power performance of Sunnan lamp (see online version for colours)

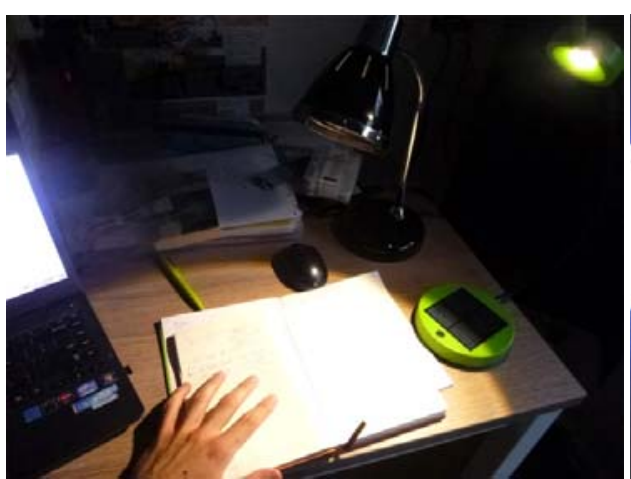

(a)

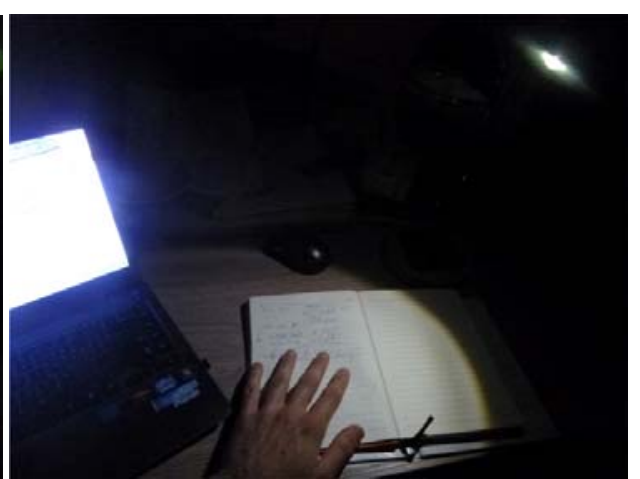

(b)

To conclude, it is favourable to look at the Sunnan lamp as two different products combined; a desk lamp and a social product. When considering it as a desk lamp it can be said that it fulfils the expectations and adheres to the performance that was indicated in the manual. On the other hand, as a desk lamp it is slightly unwieldy, as it requires daily charging and hence its usability depends largely on the respondents' discipline (in putting the solar panel outside) and the grace of the weather. As such, its shortcoming is that it is slightly unreliable and compared to other lamps, it contains limited user interaction (it only has one button, while a lot of desk lamps have multiple brightness settings). 
As a social product it is slightly more successful, though it is not completely obvious to the consumer. The policy of IKEA (the Light in the Dark project) commands that for each Sunnan bought, one is donated, such that children in countries without electricity can still read/see after sunset, with the use of the Sunnan. This is a beautiful act and combined with the educational power of the Sunnan in bringing awareness of solar-energy and the power of LEDs, the Sunnan has definitely succeeded as a social product. However, there are still some improvements possible when it comes to making the consumer aware of this side of the Sunnan desk lamp.

\subsubsection{Redesign IKEA Sunnan lamp, as proposed by 50 lead-users}

As general improvements for the Sunnan Lamp, lead-users suggest: a power toggle switch (Hi/Med/Low), so that different values of brightness could be selected when using the lamp according to the type of use. This would improve the length of use, when full brightness is not necessary. A folding stand like on a picture frame at the back of the battery pack could give it a better position towards the sun while charging. Easy access to the batteries is also essential. Another improvement could be on the width of the light beam and the light intensity. The beam should be significantly improved, because the current one is insufficient. Moreover, an LED indicator to display the battery level, or the charging status, would give the lead-user important feedback about repositioning the product, or reducing the power for preservation. For indoor use, the respondents believe that the product could be easily placed near a window, by using a suction cup and it might be more efficient to select a new type of PV cell that could achieve better performance indoors.

Figure 13 Suggestions for improvement of the Sunnan lamp, according to lead-users (see online version for colours)

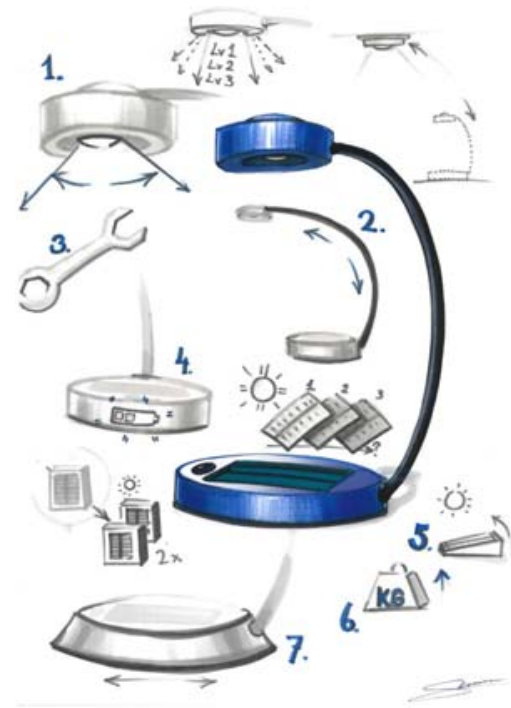

(a)

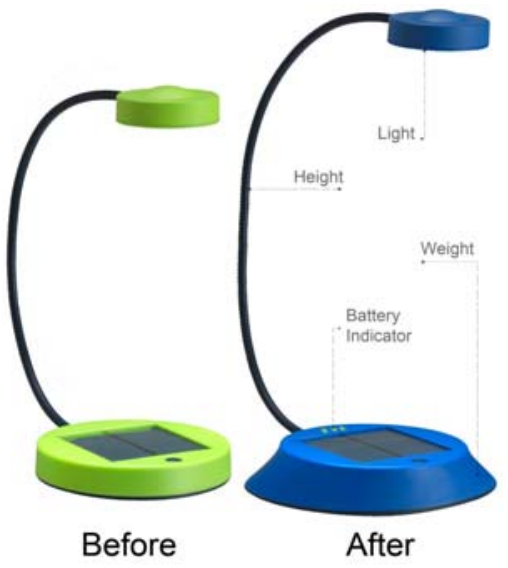

(b) 


\subsubsection{Waka Waka light and Waka Waka power}

\subsubsection{Products' features}

The Waka Waka light is a small electric light charged by a solar panel on its back surface. Two small LED lights can be used in three light intensity settings. There is only one button on the product; the user can push it multiple times for three different light intensities. Pressing the button for three seconds makes the product give off a Morse code SOS signal. The product is aimed at people who live off the grid, but can be used for different uses, such as camping. The product also has a stand, which can be used either to support the product on its own, or to prop it on a bottle by using the hole on the stand.

The next version of the Waka Waka light is the Waka Waka Power, which is a strong and solid solar charger, able to charge almost all (smart) phones or other small electronic devices within a few hours and to offer around 150 hours of lighting. The Waka Waka Power has two target groups: first world- and third world-country people. The first group could also be divided into two subgroups;

1 people who buy the Waka Waka as an act of charity

2 people who buy the Waka Waka, because they actually need a solar charger and for whom the charity is an emerging subsequent.

For the last group of people it is likely to assume that they bought the Waka Waka because they need a light and portable charger during outdoor activities, such as camping, where they lack the possibility to charge their phones or other gadgets.

\subsubsection{Lead-users' expectations before use}

The initial lead-users' impression of the product's appearance was rather strange. The shape of the product looks odd and does not enhance the functionality of the product. However, the Waka Waka looks rugged, giving it a durable appearance. It is expected that the product can be used in two main scenarios. In the first scenario, the product will be used daily by people, with no access to other sources of electricity. The product can then be used either to bring light to a whole room, or for specific everyday activities that require light, e.g. reading. In the second scenario, the Waka Waka will be used by people during camping or other similar situations, where they lack easy access to electricity.

\subsubsection{Lead-users' experience and feedback during use}

First, the Waka Waka was used by the lead-users of the field trial, as a nightstand lamp. The emitted light was quite bright, with a cold, blue tone, and it was uncomfortable when reading or looking straight at it. Moreover, the product requires no indication regarding the status of the battery. It is easy to understand that the product is not originally meant for the context that was used it in and would be more useful in different scenarios. When there is access to electricity, it seems that the product is less useful. 
Figure 14 One of the multiple uses of Waka Waka light is for reading in developing countries (see online version for colours)

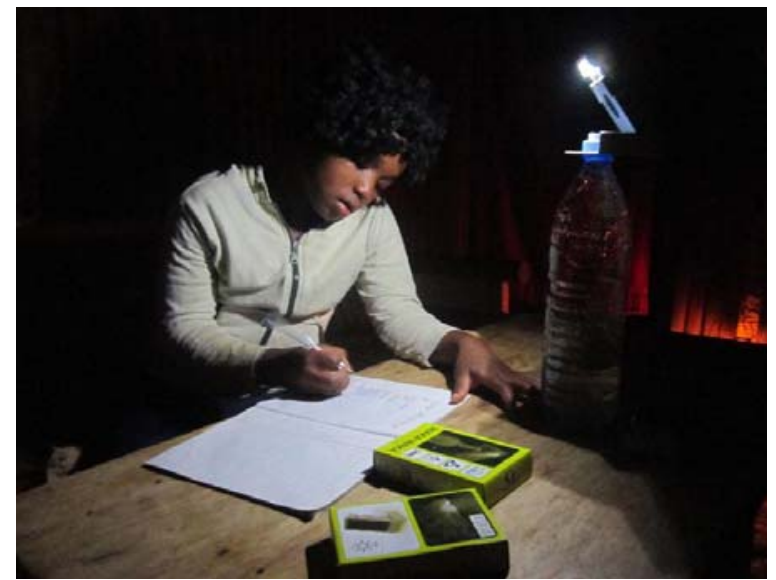

Note: The product is placed on top of a plastic bottle.

Figure 15 Waka Waka power placed on a plastic bottle of water and on a table (see online version for colours)

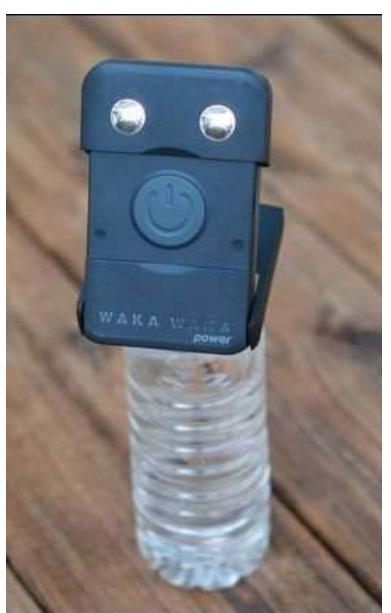

(a)

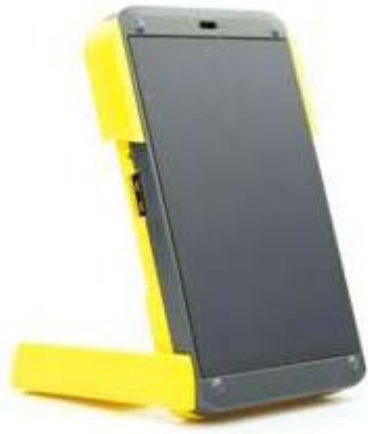

(b)

\subsubsection{General conclusions and discussion after use}

The Waka Waka is able to fulfil its functions (lighting and/or charging). However, regarding indoor activities, an alternative, non-solar powered product could also be effective. For outdoor activities and third world countries the Waka Waka power is quite an essential product. Designers thought of sustainable solution beyond PV cells, but also used recycled plastics. Furthermore, it is a very good initiative to offer Waka Waka to people in countries that really need light in the dark. Obviously, indirectly the people in 
first world countries pay for this charity project, but it is still an affordable product compared with competitors. Furthermore, it is a benefit that the Waka Waka is produced locally, when possible, so there is less transportation for shipping the products to the development countries. According to the respondents, there is still room for improvements for the Waka Waka (e.g. quality of light, brightness of the lamp, positioning of LEDs, battery status indicator, better positioning of the product).

\subsubsection{Redesign the Waka Waka light, as proposed by 15 lead-users}

From a practical point of view, the design of the Waka Waka light is quite minimalistic. It is an easy-to-use product, which works intuitively. Although there is still room for improvement. An option for upgrading would be to let the two LEDs be able to separately be pointed at any direction, no matter the position of the housing. The wellknown USB snake light could serve as an example, although this technique would renounce the protection of the LEDs and make it more vulnerable. A redesign of the LED placing could be in the form of two spherical ball hinges, which enables both LEDs separately rotation and gives the user the option to aim the lights more specifically. This means that the Waka Waka Light can still stand on a surface, while the separate LEDs can be pointed at any direction easily in order to illuminate a larger area. The big drawback of this adjustment is that it would probably cost a lot more money to develop and produce it, due to the additional hinges, in which the LEDs have to be integrated. One of the discomforts the light gives to its users is the bright peripheral light, meaning the light that directly reaches the eye if it is not placed behind the user. Placing a cap around the lights could both decrease the annoying peripheral light and also increase the amount of light, where it is actually needed. Thus, a suggestion for the redesign would be to make a small cap around the lights, so it does no longer emit light both upwards and sideward. Placing the lights a little deeper in the product and making a cap with the shell of the product could achieve this. This could also be a benefit for the LEDs, as these will be better protected.

Figure 16 Redesign of the Waka Waka lamp, as lead-users suggest, (a) scan impression concept reducing unpleasant peripheral light (b) scan impression concept positions of light

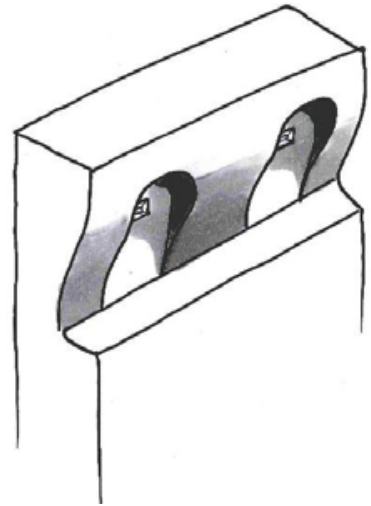

(a)

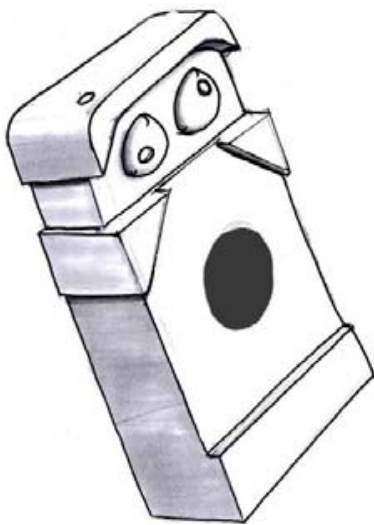

(b) 


\subsubsection{Redesign the Waka Waka power, as proposed by 4 lead-users}

The redesign of the Waka Waka power could contain a solar panel with a bigger surface, and possibly a new battery (1.5 times bigger than the current). These updates are necessary for the product to work properly and to support the charging of the new generation of (smart) phones.

\subsubsection{Little Sun light}

\subsubsection{Product's features}

Olafur Eliasson designs the Little Sun, which is a small and independent source of light, which can be used anywhere. When charged during the day, the light can be used during the evening or night. The product is intended for people with no access to electricity. To make it affordable for the target group, the light is sold in Western countries, the revenue of which is used to reduce the prices in off-grid communities. The Little Sun is a product targeted at third world communities without electricity, which means they do not have access to electrical lights in the evening. Light, which is necessary for working, studying or even just being together. A wood fire or kerosene lamps are usually used instead of electricity in third world communities. Both these light sources are dangerous, not only because they emit toxic gases, but also due to their fire hazard. This is where the Little Sun tries to help; allowing people to have a durable, safe and easy-to-use light source.

\subsubsection{Lead-users' experience and feedback during and after use}

Little Sun emits strong light, which can be useful in multiple situations and it is capable of lighting up an entire room. However, it is uncomfortable to handle, as it is a bulky product with sharp edges. The on/off switch can be hardly found in the dark. The cord that the product contains can be used to hang it into a hook.

Figure 17 Little Sun light placed on the windowsill, (a) the front side of the product (b) the backside of the product including the PV cell (see online version for colours)

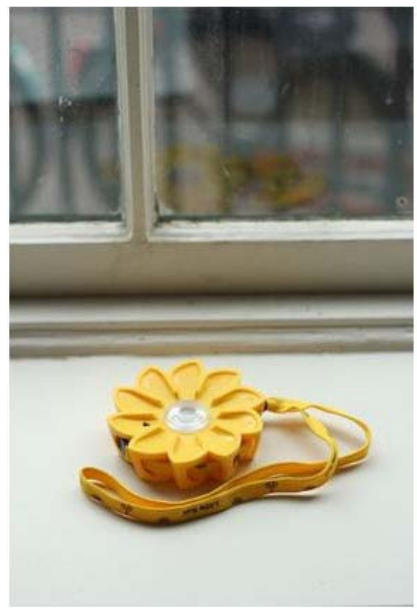

(a)

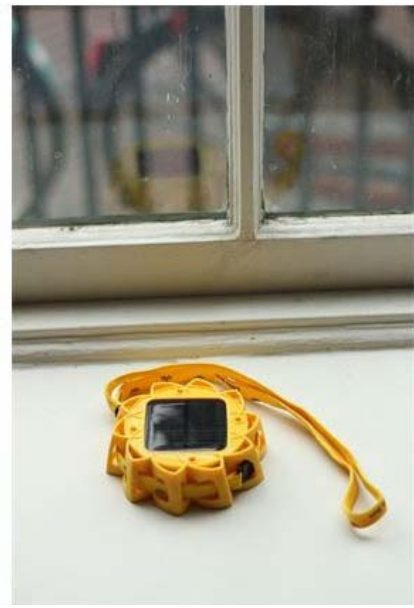

(b) 
The brightness of the Little Sun decreases from 100\% to $0 \%$ after around 7 hours of use, as it is presented in Figure 18. Generally, 7 hours of use are considered a lot and therefore the performance of the product seems to be satisfactory. However, the intensity of the light is not stable during the 7 hours of use. After 2-3 hours, the intensity becomes less strong and the light is dimmer.

Figure 18 The brightness of the Little Sun goes down from 100\% to $0 \%$ after around 7 hours of use

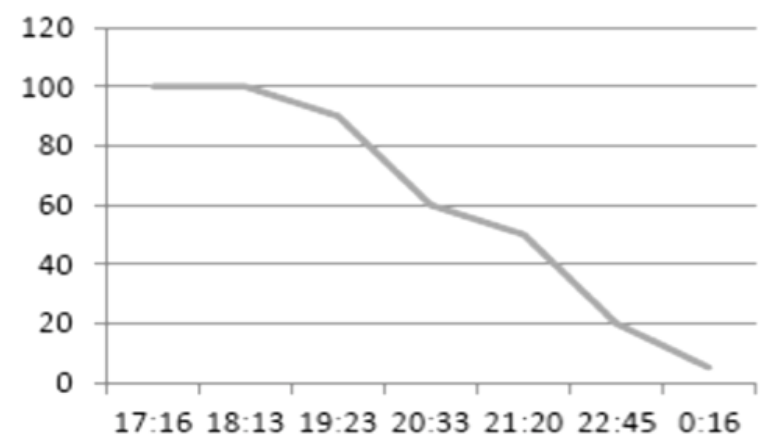

\subsubsection{Redesign the Little Sun light, as proposed by 15 lead-users}

In order to redesign the Little Sun, first it is necessary to abstract the problems. One of the main issues that users have is the safety while using the light. The sunflower-shape is very decorative, but has sharp edges. This is not ideal for little children, as it is dangerous to hurt them, while trying to use the lamp in the dark. Therefore, a new design of the product is proposed with more curved surfaces. Furthermore, a charge indicator with an LED light could be added in the product, so that the users could receive feedback regarding the status of the battery. A stand for better positioning of the product is also essential. Last but not least, lead-users propose the addition of a USB port in the product, which could offer the possibility of connection with other devices for extra charging. Below, an exploded view of the improved product is shown.

Figure 19 Redesign of the Little Sun, as lead-users suggest (see online version for colours)

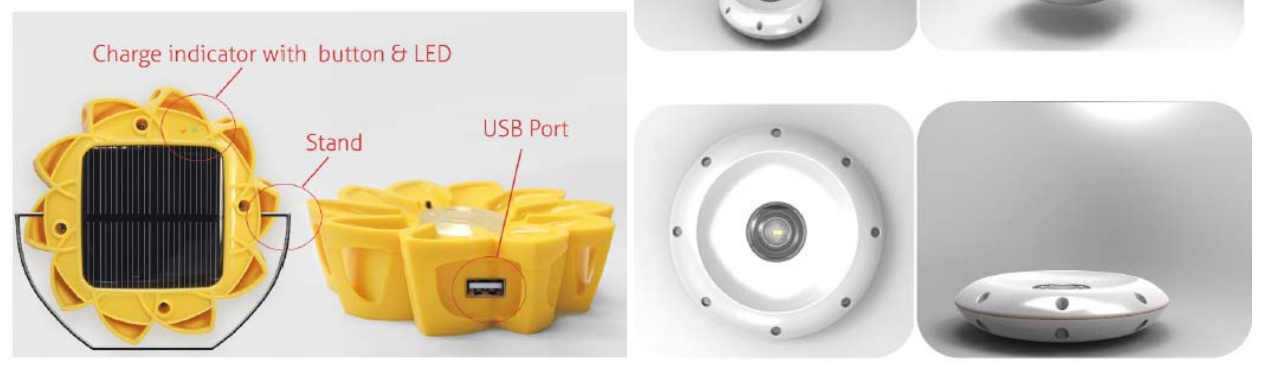




\subsubsection{Beurer kitchen weight scale}

\subsubsection{Lead-users' expectations before use}

Purely from the first appearances the product seeks to satisfy the Ideo-Pleasures of the respondents, fulfilling aspirations to feel 'Eco', both through a purchase of the product, as well as owning of the product. This is achieved through the idea of a solar powered scale, presenting itself as an 'Eco' and sustainable alternative. The user will gain a greater appreciation for the product, increasing relationships and gaining the ability to strike up a conversation about the product, also because it looks and appears modern.

\subsubsection{Lead-users' experience and feedback during use}

According to lead-users, it seems that the scale works fine and precisely during the day with sunlight and it does not need any charging. It works each time you need it, just as the producers promise. The scale weighs small amounts up to $5.5 \mathrm{~kg}$ and has a graduation of 0.1 gr. On the display, a battery bar is showed on the left top, indicating that the battery stays constantly half full even after 4 hours of sunbathing. When using the scale during the evening, the product faces difficulties catching enough light.

\subsubsection{General conclusions and discussion after use}

The power on time depends on the light intensity, whereas the discharge time does not. This suggests that there may be a capacitor inside the product. The purpose of the capacitor is to power the scale, when the stream of light hitting the panel is disrupted. Being powered by a capacitor may be an issue in the scenario that a large object is placed on the scale, covering the panel and disrupting the direct light. This is not a desirable feature, since it gives a limited amount of time to weigh the object. The kitchen scale weighs with an acceptable order of accuracy for its use purpose. However, this uncertainty may increase, when the object's centre of mass is not placed in the middle of the scale, since it has only one sensor in the middle. If the centre of mass is placed off centre, it creates a moment, increasing the measured mass. This is not an issue for the scale's functionality, since while cooking or baking, one gram more or less will not make any difference.

Figure 20 The Beurer kitchen weight scale is being used during the field trial (see online version for colours)

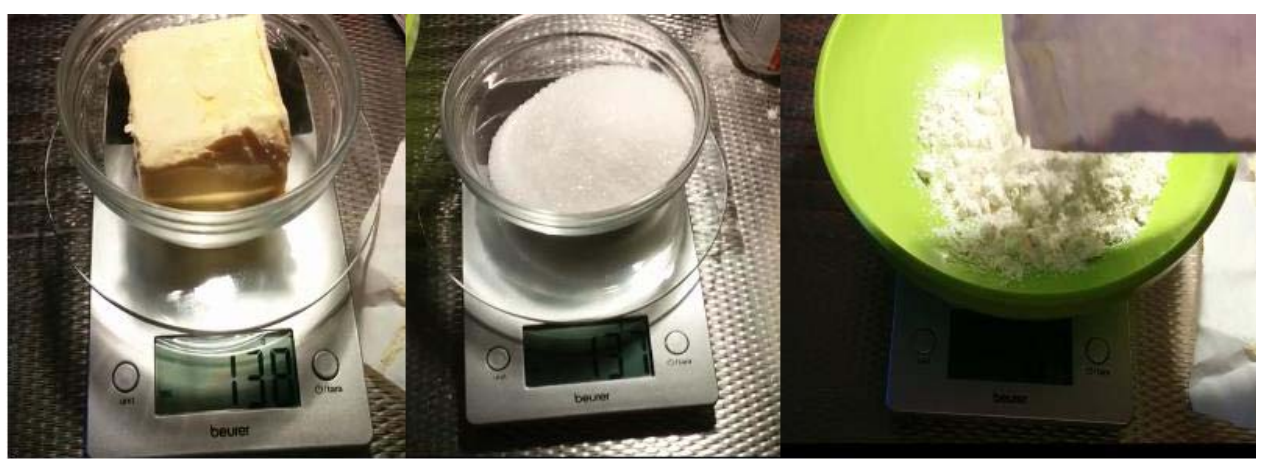


Overall, the scale does not meet its initial expectations as, very often, at least half a minute is required before it can be used. In the case that no natural light is available, an alternative light source is required. The fact that a more consuming energy source is required to power the product is not as efficient as directly taking the required power from the grid.

\subsubsection{Redesign the Beurer kitchen scale, as proposed by ten lead-users}

The most efficient way of improving the product's performance, without drastically altering the required technology was to allow the PV cells to catch more light. The first way to achieve this is by removing the 'hovering' glass plate. In order to avoid the shadow of the object that is being weighted to block out light for the PV cells, the PV cells were distributed over the surface of the product in a different way, as Figure 21 illustrates. In that way, they cannot both be fully blocked out, which means that there should always be some power available. The new design that is proposed would preferably have a quite similar appearance to the old one, which is a quite smooth and modern look.

Figure 21 Redesign of the kitchen weight scale (see online version for colours)

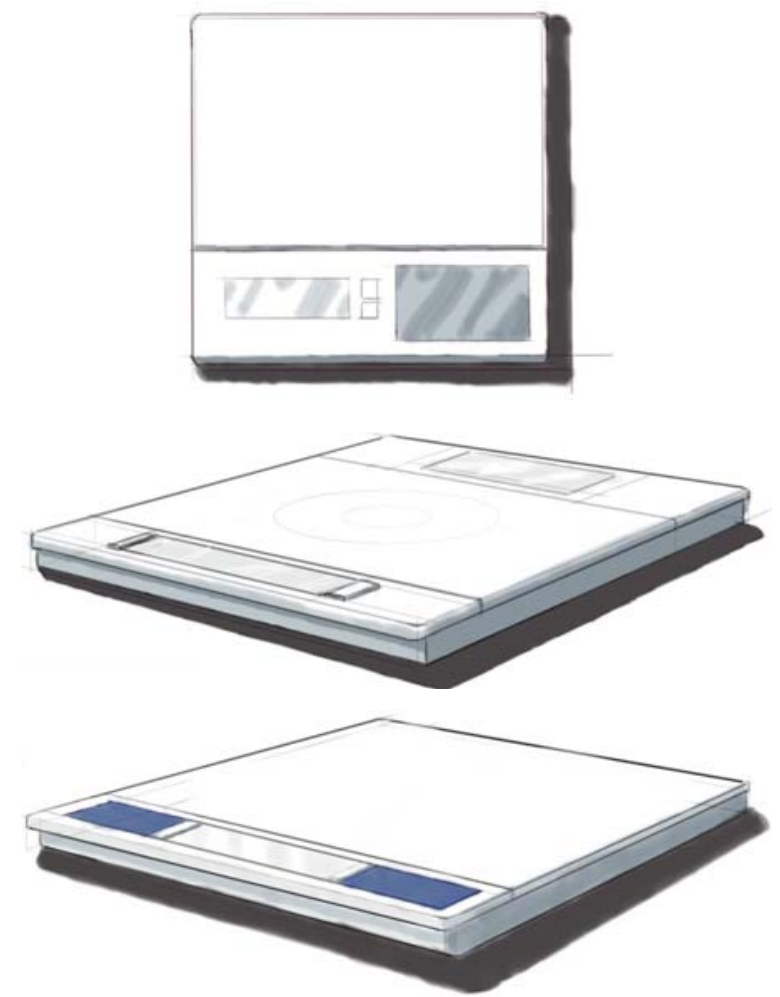

Note: Sketches based on the repositioning of the PV cells and removal of the glass plate. 


\subsubsection{Logitech solar keyboard}

\subsubsection{Lead-users' expectations before use}

Any computer or tablet can use Logitech solar keyboard. It performs absolutely powered by the sun or indoor lighting and there is no need for charging. It is possible to be used with all kinds of digital devices. It looks very sleek and professional, and it is expected that the intended use is in a work environment. Owing to its portability and the solar powering, it does not need to be added to the power grid and it can be used everywhere. The PV cells are intended to make the product absolutely independent of the grid and to eliminate the batteries' charging. Logitech claims that the keyboard has a three-month battery life with no light. Taking into account that a keyboard does not take much power to operate, it will most likely not drain the battery too fast.

Figure 22 The Logitech K750 PV keyboard (see online version for colours)

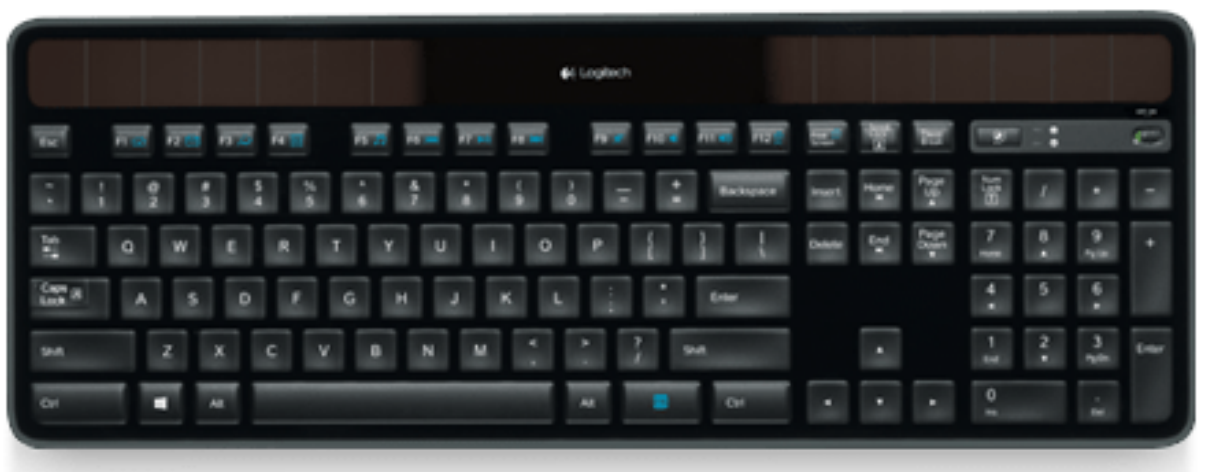

\subsubsection{Lead-users' experience and feedback during use}

Generally, the keyboard worked very well and the respondents were satisfied by its performance. They felt that it is a very beautiful design, both in look as in user friendliness. Furthermore, the fact that it is solar powered is an added bonus. During the testing, the keyboard had a light interaction of less than 1 hour each day. At the fourth day of the testing, the solar application (see Figure 23) showed for the first time a different value than $100 \%$, a $99 \%$ state of charge (SOC) of the battery. This means that with a light use of the keyboard, the battery would be able to run for one full year without charging or in total darkness. However, there are more active users, who use the keyboard more hours per day, but even in that case, the battery would still be able to discharge at around 1-2\% each day, with then a total operation time of around three months. However, the cases that are described here are quite extreme, since the PV keyboard would normally always recharge the battery by using the installed solar cells. After the test, the battery showed the next day a SOC of $100 \%$. 
Figure 23 The solar application of the Logitech solar keyboard, showing the light brightness and the charging status of the battery before starting the test and after four days of use (see online version for colours)

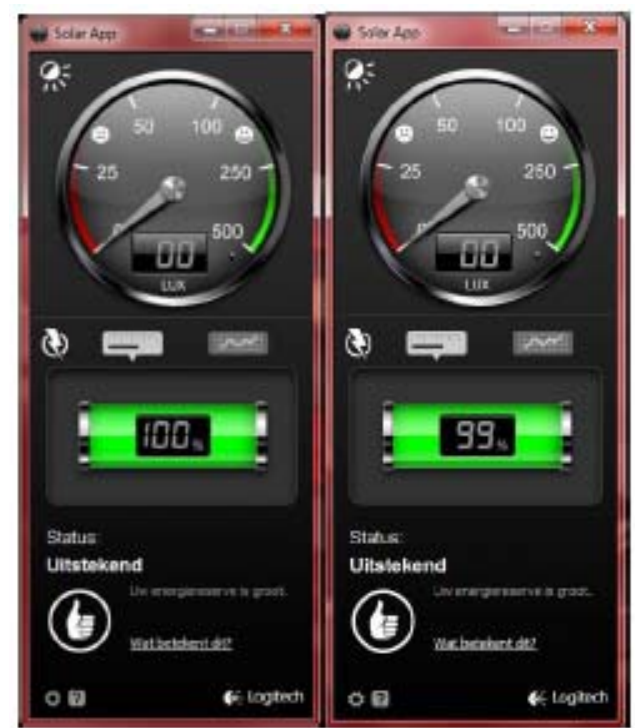

\subsubsection{General conclusions and discussion after use}

The keyboard worked perfectly during the period which was used. The PV panels integrated in the product did their work sufficiently, by keeping the battery charged up at $100 \%$ almost continually. The simulations of the power management of the PV keyboard showed that even by a more intensive usage of the PV keyboard, the configuration of battery and PV cell by the manufacturer would in the worst case ensure at least 13 days of use till the battery would run out, under low lighting conditions. The combination of battery and PV cells made the product totally power independent from the usual keyboard, which are bound to periodical change of batteries. The negative criticism towards the PV keyboard was insignificant and subjective regarding small issues about the product's design.

According to lead-users' opinions, the PV keyboard was praised about its design, but finally it was also criticised about its price. Most respondents would not wish to pay double price for a product, just because of the integrated PV cells. However, even though the product is quite expensive, it seems reliable. The support and the service, which one can get from Logitech is also valuable. The manufacturer offers a three year warranty and also a very good forum and website, where every user can easily share with others their problems and experiences. The solar application is also very useful since it keeps the user always informed about the battery's SOC and also about the indoor illumination.

\subsubsection{Redesign the solar keyboard by Logitech, as proposed by six lead-users}

Generally, most respondents were satisfied with the keyboard's design. However, the easy transportation of the product is a feature that could be improved. Therefore, to make it easier to transport the keyboard, the removal of the number-pad is a possible choice. 
This makes the keyboard much shorter and easier to transport, as the main focus now lies on the use in combination with a tablet computer. This means that the USB connection could be replaced by a connection via Bluetooth. As the Bluetooth connection uses more power, and given the fact that the keyboard was overpowered, but reliable during the field trial, it seems that the system could support the Bluetooth connection. In a marketing sense this small adjustment will make the keyboard more versatile, as it will be introduced to the tablet market that mostly uses a Bluetooth connection.

The difference in quality per feature is arranged as good $(+)$, medium $(+-)$ and bad (-) in Table 3.

Table 3 Product comparison, according to 100 users' feedback

\begin{tabular}{|c|c|c|c|c|c|c|}
\hline $\begin{array}{l}\text { PV product/number of } \\
\text { users per product } n\end{array}$ & $\begin{array}{c}\text { Sunnan } \\
\text { lamp } \\
n=50\end{array}$ & $\begin{array}{c}\text { Waka } \\
\text { Waka } \\
\text { light } \\
n=15\end{array}$ & $\begin{array}{c}\text { Waka } \\
\text { Waka } \\
\text { power } \\
n=4\end{array}$ & $\begin{array}{l}\text { Little Sun } \\
\quad n=15\end{array}$ & $\begin{array}{c}\text { Beurer } \\
\text { kitchen } \\
\text { scale } \\
n=10\end{array}$ & $\begin{array}{l}\text { Logitech } \\
\text { solar } \\
\text { keyboard } \\
n=6\end{array}$ \\
\hline Form & +- & + & + & + & +- & + \\
\hline Compactness & +- & + & + & + & - & + \\
\hline Use and repair & + & + & + & +- & +- & + \\
\hline Safety & + & + & + & + & + & + \\
\hline Solidity & - & + & + & +- & - & +- \\
\hline Price affordable & + & - & - & +- & - & +- \\
\hline \multicolumn{7}{|l|}{ Technical details } \\
\hline $\begin{array}{l}\text { Performance } \\
\text { outdoors/indoors }\end{array}$ & $+1-$ & $+1-$ & $+1-$ & $+1-$ & - & + \\
\hline Charge capacity & - & + & - & + & - & + \\
\hline Efficiency & +- & +- & +- & + & - & + \\
\hline Adjustability & - & - & - & +- & - & + \\
\hline Durability & - & + & + & - & - & + \\
\hline Sustainability & + & + & + & + & +- & + \\
\hline $\begin{array}{l}\text { Environmental } \\
\text { friendly character }\end{array}$ & + & + & + & + & + & + \\
\hline
\end{tabular}

\section{Discussion and conclusions}

In this study, we focused on lead-users' interaction with PV products through a practice-oriented approach. We used a questionnaire to identify users' needs and expectations from the PV products and the methods of self- and direct-observation for the investigation of the user behaviour during the interaction. The study of the user behaviour is a quite difficult and challenging task and the combination of various methods is necessary for reliable results. Therefore, in our study, we conducted not only field trials, but also technical tests for a better understanding of the PV technology by the users.

The tested sample of users for the observation of their behaviour with the PV products consisted of 100 students of Industrial Design Engineering Department of Technical University of Delft. The specific sample used quite high standards for the characterisation of the products' quality and offered a critical view of the products' 
usability, design and performance. It seems that the tested sample of lead-users had a more critical look than a regular user, owing to their educational background in the field of product design and they are more ahead than other students with less relevant educational experience. The specific user type of this study cannot be represented as a regular user or consumer. This user may be considered as a 'lead-user', since he/she was asked to follow some specific tasks for the evaluation of the products, which might not be recognisable by a regular user. Moreover, the 'lead-users' of this study proposed solutions and ideas about redesigning the PV products, which is pretty uncommon for regular users to provide such a feedback. On the one hand lead-users can notice and forecast problems that might occur in the future, but on the other hand owing to their educational background and their knowledge in the field of product design and engineering, they understand the boundaries of design and technology in the products. These features are not visible and easily understandable by the regular users, who usually criticise the outlook, usability and performance of the products, without caring about the above-mentioned limits. Hence, the beliefs of the lead-users in this study do not reflect the real behaviour of a simple user, but they could be quite influential regarding the future successful use of the PV products.

The results revealed that the usability, the design, the aesthetics and the performance of a PV product are quite important factors for lead-users. Respondents are quite enthusiastic with PV products if useful and functional, but they need more reliable PV products with a more appealing design. It was noticed that lead-users' expectations before use and their experience afterwards, deviate significantly. Quantitatively, results show that around $40 \%$ of the respondents are disappointed with the PV product that they used, $38 \%$ found the product useless, around $60 \%$ believe that the design of the product is of low quality, $88 \%$ of the respondents would not buy the PV product and around $70 \%$ believe that the price of the PV product does not match its quality and performance. It is remarkable to notice that around $66 \%$ of the respondents would prefer a product that can be charged by a cable with a plug, rather than a PV-powered product.

Going back to Sander's (2002) theory about the different experience characteristics of users, we tried to distinguish the four categories of the 'obvious', the 'visible', the 'unspoken' and the 'dormant' features of users. On the one hand, observing the leadusers interacting with the products easily identified the 'obvious' and 'visible' features. First, the 'unspoken' and the 'dormant' were investigated through questions regarding users' thoughts before, during and after the field trial. Lead-users enjoyed the benefit to actively interact with the products and criticise products' characteristics, such as the design, the usability, the performance, the aesthetics or any other feature that was important for them. Furthermore, it was interesting to notice what lead-users believe regarding the significance of these products and what they propose for a possible products' redesign. Last but not least, in this study we uncovered lead-users' behaviour while interacting with PV products and we focused mainly on the 'unspoken' and 'dormant' features, which are important for designers.

Yet the testing sample is limited (six PV products) and general conclusions cannot be drawn. However, results are important, as they represent someof the PV products that are commercially available and easily accessible to consumers and basic user behaviour with them. Since the survey outcomes are strongly affected by the type of the specific user, it is unlikely that regular users will have similar behaviour to the product's use. Therefore, the specific results could not be extended to all target groups. To finish, the impressions of the lead-users about the PV products are not necessarily analogous to the regular 
users'. Nevertheless, the results of this study and the specific users' reflections could inspire the future design and usability of PV products. We believe that the findings of this study will be valuable for designers towards a better understanding of the user behaviour and, combined with technical data of PV products, could be used for the design of high efficiency PV products.

\section{References}

Apostolou, G. and Reinders, A.H.M.E. (2012) 'A comparison of design features of 80 PV-powered products', Proceedings of the 27th EUPVSEC, Frankfurt, Germany, pp.4227-4232.

Apostolou, G. and Reinders, A.H.M.E. (2014) 'Overview of design issues in product-integrated photovoltaics', Energy Technology, article first published online: 5 March 2014, DOI: 10.1002/ente.201300158, C2013 Wiley-VCH Verlag GmbH \& Co. KGaA, Weinheim.

Apostolou, G., Verwaal, M. and Reinders, A.H.M.E. (2014) 'Modeling the performance of product integrated photovoltaic (PIPV) cells indoors', Proceedings of 26th EU PVSEC, Amsterdam, The Netherlands.

Bakker, C.A., van Eijk, D.J., Silvester, S., Reitenbach, M.E.F.R., de Jong, A.M., Keyson, D.V. and Scott, K. (2010) 'Understanding and modelling user behaviour in relation to sustainable innovations: the living lab method', in Horvath, I., Mandorli, F. and Rusak, Z. (Eds.): Proceedings of TMCE 2010 Symposium, s.1.: TMCE (TUD), pp.1-12.

Fulton, S.J. (2003) 'The experience evolution: developments in design practice', The Design Journal, Vol. 6, No. 2, pp.39-48, IDEO, Berg.

Jelsma, J. (2006) 'Designing 'moralized' products; theory and practice', in Verbeek, P.P. and Slob, A. (Eds.): User Behavior and Technology Development; Shaping Sustainable Relations between Consumers and Technologies, pp.221-231, Springer, Dordrecht, The Netherlands.

Jelsma, J. and Knot, M. (2002) 'Designing environmentally efficient services; a 'script' approach', The Journal of Sustainable Product Design, Vol. 2, No. 3, pp.119-130.

Kakee, S. (2008) Co-Designing Sustainable User Practices; An Exploratory Study for the Living Lab Project, MSc Thesis, Industrial Ecology, Delft University of Technology.

Reich, N.H. et al. (2007) 'A solar powered wireless computer mouse: design, assembly and preliminary testing of 15 prototypes', Proceedings of 22st European Photovoltaic Solar Energy Conference, Milan.

Reich, N.H., Elzen, B., Netten, M.P., van Sark, W.G.J.H.M., Alsema, E.A., Veefkind, M. and Silvester, S. (2008) 'Practical experiences with the PV powered computer mouse "sole-mio"', Proceedings of 23rd European Photovoltaic Solar Energy Conference and Exhibition, 1-5 September 2008, Valencia, Spain, pp.3121-3125.

Reinders, A.H.M.E. and van Sark, W.G.J.H.M. (2012) 'Product-integrated photovoltaics', in Sayigh, A. (Ed.): Comprehensive Renewable Energy, Vol. 1, pp.709-732, Elsevier, Oxford.

Reinders, A.H.M.E., Diehl, J.C. and Brezet, H. (2012) The Power of Design: Product Innovation in Sustainable Energy Technologies, October, Wiley, Delft, Netherlands.

Rodríguez, E. and Boks, C. (2005) 'How design of products affects user behaviour and vice versa: the environmental implications', Proceedings of EcoDesign 2005, Union of Ecodesigners, Tokyo, pp.1-8.

Rooden, T. and Kanis, H. (2000) 'Anticipation of usability problems by practitioners', Proceedings of the Human Factors and Ergonomics Society 44th Annual Meeting, San Diego.

Sanders, E.B.N. (2002) 'From user-centred to participatory design approaches', in Frascara, J. (Eds.): Design and the Social Sciences, Taylor \& Francis, London.

Sanders, E.B.N. (2006a) Design Serving People, Copenhagen Cumulus Working Papers, University of Art and Design Helsinki. 
Sanders, E.B.N. (2006b) 'Design research in 2006', Design Research Quarterly, Vol. 1, No. 1, pp.1-8.

Shackel, B. (1984) 'The concept of usability', in Bennet, J. et al. (Eds.): Visual Display Terminals, pp.45-88, Prentice-Hall, Inc., Englewood Cliffs, NJ.

Smit, E., Stevels, A. and Sherwin, C. (2002) 'User centred ecodesign: experiences from the design of a human-powered remote control', Proceedings of Care Innovation 2002, 25-28 November, IEEE, Vienna.

von Hippel, E. (1982) 'Appropriability of innovation benefit as a predictor of the source of innovation', Research Policy, Vol. 11, No. 2, pp.95-115.

von Hippel, E. (1986) 'Lead users: a source of novel product concepts', Management Science, July, Vol. 32, No. 7, pp.791-805.

Vredenburg, K., Isensee, S. et al. (2002) User-Centered Design; An Integrated Approach, Prentice-Hall, Upper Saddle River, NJ.

Wever, R., van Kuijk, J. and Boks, C. (2008) 'User-centred design for sustainable behaviour', International Journal of Sustainable Engineering, Vol. 1, No. 1, pp.9-20. 